
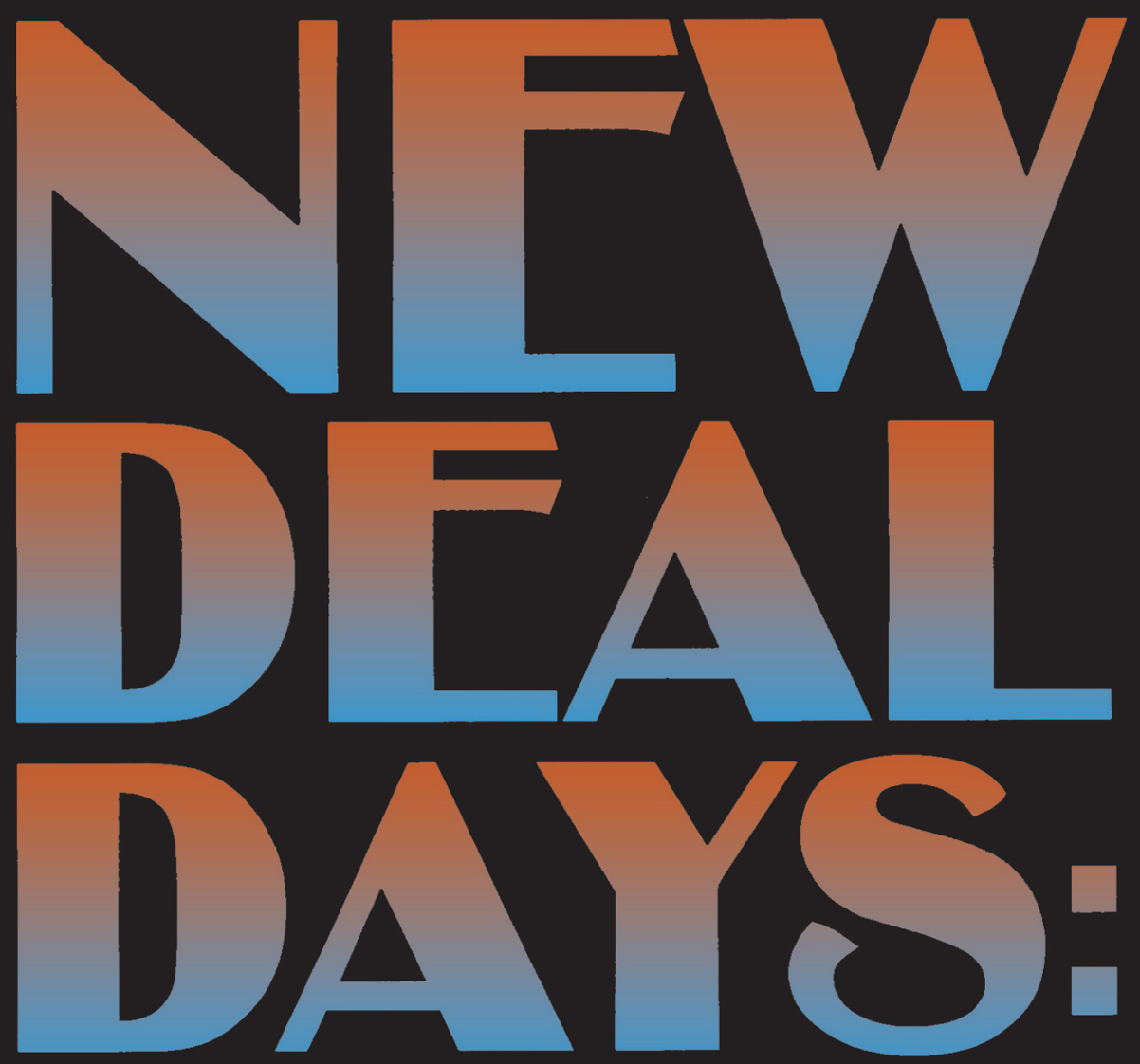

\title{
$1933-1934$
}

\section{Eli cimzberg}




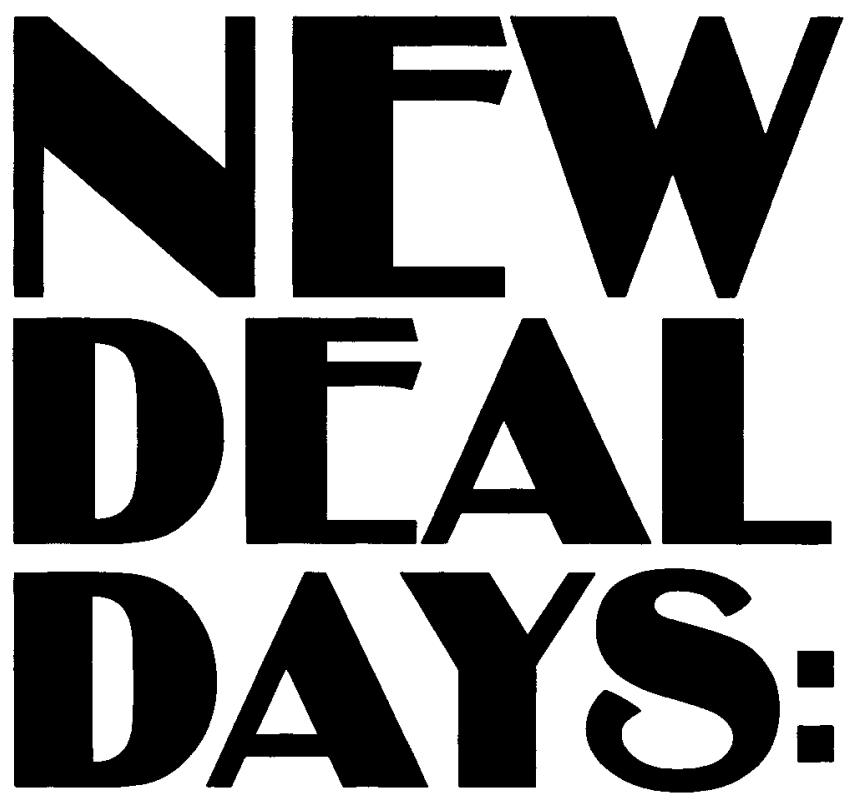

1933-1934 


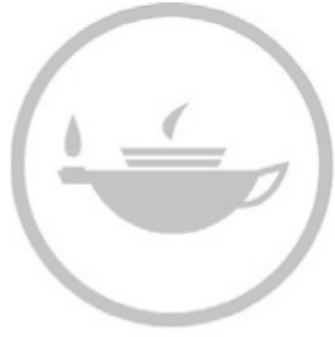

Taylor \& Francis
Taylor \& Francis Group http://taylorandfrancis.com 

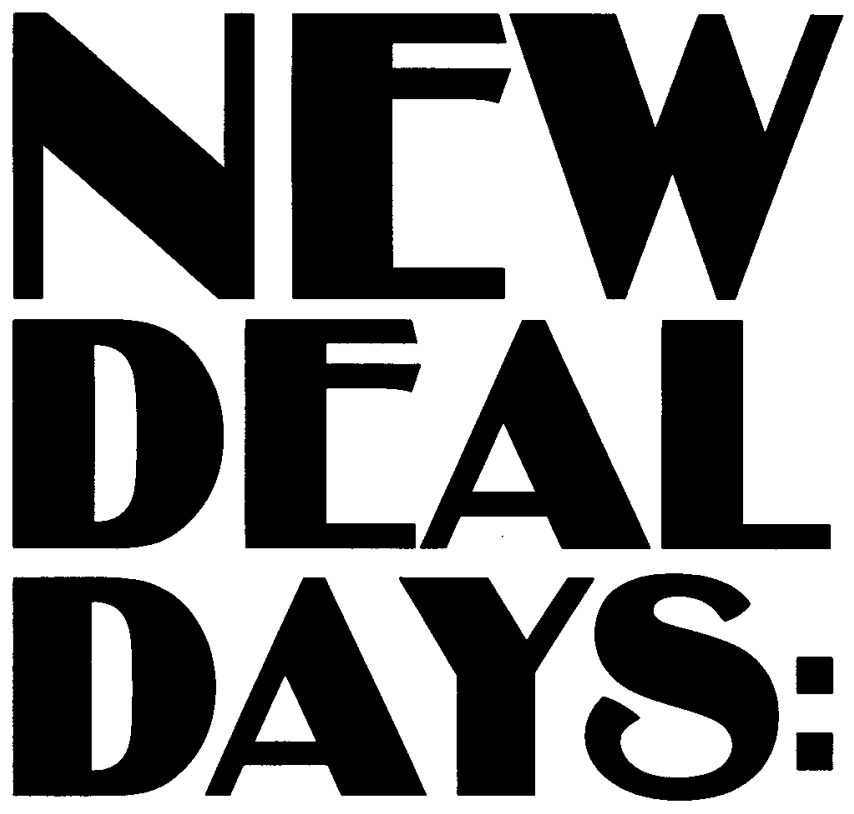

\section{3-1934}

\section{Eli Ginzberg}

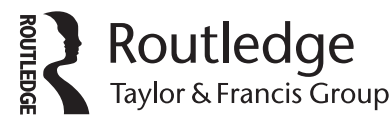

LONDON AND NEW YORK 
First published 1997 by Transaction Publishers

Published 2017 by Routledge

2 Park Square, Milton Park, Abingdon, Oxon OX14 4RN

711 Third Avenue, New York, NY 10017, USA

Routledge is an imprint of the Taylor \& Francis Group, an informa business

Copyright $\mathbb{C} 1997$ by Taylor \& Francis

All rights reserved. No part of this book may be reprinted or reproduced or utilised in any form or by any electronic, mechanical, or other means, now known or hereafter invented, including photocopying and recording, or in any information storage or retrieval system, without permission in writing from the publishers.

Notice:

Product or corporate names may be trademarks or registered trademarks, and are used only for identification and explanation without intent to infringe.

Library of Congress Catalog Number: 97-2259

Library of Congress Cataloging-in-Publication Data

Ginzberg, Eli, 1911-

New Deal days, 1933-1934 / Eli Ginzberg.

p. $\mathrm{cm}$.

ISBN 1-56000-331-6 (alk. paper)

1. United States-Economic conditions-1918-1945. 2. United StatesSocial conditions-1933-1945. 3. New Deal, 1933-1939. I. Title. HC106.3.G513 1997

338.973'009'043—dc21

97-2259

CIP

ISBN 13: 978-1-56000-331-1 (hbk) 
To my Columbia University teachers and friends

\author{
Adolph A. Berle \\ Thomas C. Blaisdell \\ John Maurice Clark \\ Raymond Moley \\ Rexford Guy Tugwell \\ Leo Wolman
}

who made it possible for me to see the New Deal from the inside in 1933-34. 


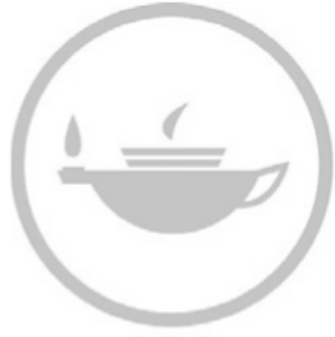

Taylor \& Francis
Taylor \& Francis Group http://taylorandfrancis.com 


\section{Contents}

Setting the Stage 1

1. The New Deal 5

2. Big Business 23

3. The University 37

4. Southwest 53

5. Hollywood 69

6. People and Places 83 


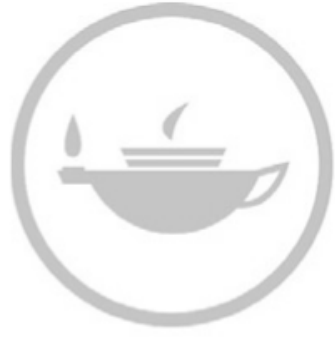

Taylor \& Francis
Taylor \& Francis Group http://taylorandfrancis.com 


\section{Setting the Stage}

The sketches that comprise this volume were written in 1933-34, the year that I travelled through the United States visiting the headquarters of forty large corporations including General Electric, Eastman Kodak, U.S. Steel, Standard Oil of New Jersey (Exxon), General Motors, Sears Roebuck, Goodyear Tire and Rubber, International Harvester and many others. I visited forty states during a ten-month trip during which I covered 40,000 miles.

Having successfully defended my doctoral dissertation, The House of Adam Smith (Columbia University Press, 1934) in the spring of 1933; having been awarded a William Bayard Cutting Traveling Fellowship that spring, I persuaded the Columbia University authorities to allow me to spend my Cutting year visiting large U.S. corporations rather than "absorbing culture" in London, Paris, and Rome in accordance with established practice for Cutting fellows. The fact that I had studied at Heidelberg and Grenoble some years earlier helped to persuade the Columbia authorities.

In seeking a change in venue I stressed in my request that having spent the last years attending lectures and reading books about economics, I felt an urgency to learn first hand about how the U.S. economy had weathered the most devastating depression in the nation's history and how it was responding to President Roosevelt's New Deal initiatives.

I had considered seeking a publisher for this volume in 1934, but one of my favorite professors had advised me against doing so pointing out that it would not be helpful for a young scholar starting on an academic career to be identified as the author of a nonscholarly output. On several occasions in the following decades I considered whether the manuscript might be published but I was unable to locate a copy either in my files at home or at Columbia. Recently it showed up on my desk at home probably as a consequence of housecleaning after my wife Ruth's death in the late summer of 1995. 
My field investigations in 1933-34 resulted in a scholarly tome-The Illusion of Economic Stability that Hauper and Brothers published in 1939. But I believe that the sketches that comprise this volume which reflect the impressions, reflections, and reactions of a provincial New Yorker in his first encounters with the South, Midwest, Southwest, and West in the months that President Roosevelt and his advisors were struggling to turn the nation around after its severe buffeting from the Great Depression may be of interest to various readers, the overwhelming majority of whom have no first hand knowledge of the Great Depression (1929-1933), the greatest domestic crisis in the nation's history, the Civil War alone excepted, and the beginnings of the New Deal that FDR initiated in 1933-34.

The William Cutting Traveling Fellowship that I received in the spring of 1933 carried a stipend of $\$ 1800$ payable in two installments. As a close reader will observe I was preoccupied during most of my fellowship year with the possible, even likely, failure of the New Deal, which I feared would unleash a major inflation such as I had encountered on a trip to Germany as an eleven-year-old in 1922 when the mark had declined from 4 to 250 to the dollar, before it took off in the following year to a point when the value of paper on which the currency was printed exceeded its designated monetary value. The fact that I had studied "Money and Banking" with H. Parker Willis at Columbia-who had served as senior staff advisor to Senator Carter Glass at the time when the senator was steering the Federal Reserve Act through the Senate (1913) also made me a "hard money" man fearful of any and all tampering with the value of the dollar.

To underscore my disquietude about how the New Deal initiatives might undermine the value of the dollar consider the following. On receipt of the first installment of my fellowship money I wrote to Harry George Friedman (latterly the president of General American Investors) and a life-long friend of my parents to please buy me some conservative stocks so that I would be able to afford the skyrocketing prices for gasoline that I feared would prevail when I got ready to drive back East after the New Year from California. I recall his reply: "You are sufficiently young not to realize that logic governs neither the actions of men nor the gyrations of the stock market. However in accordance with your request I have bought today 25 shares of Endicott-Johnson stock for your account." 
I recall my principal mentor at Columbia University Wesley Clair Mitchell telling me that Willis had never altered his views on inflation since the time when they were graduate students at the University of Chicago shortly after the turn of the century. I too never shook off my early fears of inflation, based on my visit to Germany in 1922, a fear that led me to misdiagnose many developments before and after the onset of the New Deal.

A few points about dollars and prices in the early days of the New Deal. My mother, who did not drive, located a 1926 Buick sedan with a price tag of $\$ 200$ which I bought. After driving it for 40,000 miles I was able to sell it for scrap on my return to New York City in May 1934 for $\$ 40$. If my memory does not play me false I was able to buy six gallons of gas for one dollar most of the year that I was in the field except that I recall that in Los Angeles the price dropped to eight gallons for the dollar.

Since I was interviewing senior corporate executives some of whom might have occasion to telephone me I had to put up at a respectable hotel. With very few exceptions I was able to obtain accommodations for $\$ 1.50$ per night, with no extra charge for parking my car usually at the rear of the hotel. In Detroit, which was seriously overbuilt with hotel accommodations, I paid for six nights for a seven-night stay.

One could get a multicourse breakfast usually at one of the chain drugstores for twenty-nine cents-fruit, eggs, toast, and coffee. Except when I was on the road I was always a guest at lunch, and frequently at dinner. After eleven months in the field I returned to New York City with several hundred dollars of my fellowship grant still unspent; in part because in Los Angeles I was a guest during a three-week stay with old friends from New York City who had relocated.

There was a great deal askew with the U.S. economy in the early days of the New Deal but hotel rooms, meals, gasoline were surely within the reach of the lucky ones like myself who had been awarded a liberal fellowship by a major university; and who spent the year interacting mostly with executives at their corporate headquarters and at their homes. 


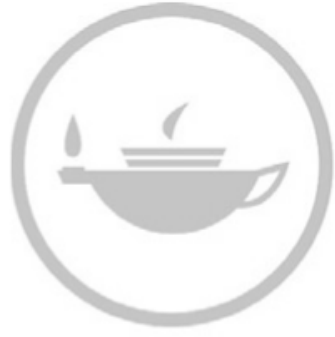

Taylor \& Francis
Taylor \& Francis Group http://taylorandfrancis.com 